\title{
New artery of knowledge: 3D models of angiogenesis
}

\author{
Eleonora Zucchelli1, Qasim A Majid1 and Gabor Foldes',2 \\ ${ }^{1}$ National Heart and Lung Institute, Imperial College London, London, UK \\ ${ }^{2}$ Heart and Vascular Center, Semmelweis University, Budapest, Hungary
}

Correspondence should be addressed to G Foldes: g.foldes@imperial.ac.uk

\begin{abstract}
Angiogenesis and vasculogenesis are complex processes by which new blood vessels are Key Words formed and expanded. They play a pivotal role not only in physiological development and growth and tissue and organ repair, but also in a range of pathological conditions, from tumour formation to chronic inflammation and atherosclerosis. Understanding the multistep cell-differentiation programmes and identifying the key molecular players of physiological angiogenesis/vasculogenesis are critical to tackle pathological mechanisms. While many questions are yet to be answered, increasingly sophisticated in vitro, in vivo and ex vivo models of angiogenesis/vasculogenesis, together with cutting-edge imaging techniques, allowed for recent major advances in the field. This review aims to summarise the three-dimensional models available to study vascular network formation and to discuss advantages and limitations of the current systems.
\end{abstract}

\section{Introduction}

The major role of the vascular system is to supply sufficient levels of oxygen and nutrients to the bodily organs. Naturally, any disruption to this system manifests itself as a host of diseases including, but not limited to, stroke, peripheral artery disease and other ischaemic cardiovascular diseases. Furthermore, the unregulated expansion of the vasculature during tumour angiogenesis can have detrimental consequences resulting in cancer metastasis. However, repair of the vasculature can hold immense therapeutic potential in tissue engineering approaches. Therefore, a greater understanding of the underlying endothelial biology that governs vessel formation and remodelling is required; this is a complex process driven by a combination of cells in tandem with an array of factors and signalling cascades. Moreover, other than blood vessels, another type of vasculature exists, which form the lymphatic network. Lymphatic vessels are unidirectional, blind-ended capillaries, which arise from the venous vasculature, and they are also formed by endothelial cells. The lymphatic system has the fundamental role of draining interstitial fluids from the tissues, and it is also involved in the immune surveillance of the body $(1,2)$. A great variety of assays has been developed to study blood and lymphatic vessel formation, each with advantages and limitations. These bioassays allowed to study the biology of angiogenesis and vasculogenesis, to test drugs that can modulate angiogenesis in normal and pathological conditions, and to discover mechanisms of lymphangiogenesis (3). This review aims to focus on 3D models of blood vessel formation. https://vb.bioscientifica.com

https://doi.org/10.1530/VB-19-0026
(C) 2019 The authors Published by Bioscientifica Ltd

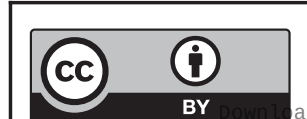

This work is licensed under a Creative Commons Attribution 4.0 International License. 


\section{Angiogenesis and vasculogenesis}

Vasculogenesis refers to the de novo formation of the primitive vascular plexus and the heart during embryonic development, via the differentiation of endothelial cell precursors (hemangioblasts) into endothelial cells (4). Angiogenesis refers to the formation of new vessels from pre-existing ones, thus remodelling of the primitive vascular plexus during and after development (5). It occurs by two distinct mechanisms, namely endothelial sprouting and intussusceptive microvascular growth. Endothelial sprouting is based on EC migration into the connective tissues, via degradation of the basement lamina, and formation of a new functional capillary $(1,6,7)$, while intussusceptive microvascular growth is the expansion of the existing capillary network, by diving the vessel lumen through the insertion of transcapillary tissue pillars $(8,9)$.

\section{Clinical unmet need}

Angiogenesis refers to the formation of an adequate, interconnected network of vascular tubes that are a prerequisite to controlled blood flow and is, therefore, a key process in organ growth and development. Indeed, the increased generation of small vessel networks can lead to the regeneration of the tissue environment in ischaemic cardiovascular diseases after injury or atherosclerosis. As the first reports showed decades ago, angiogenesis is also indispensable for tumour growth and transition towards a malignant state capable of metastasis (10). Moreover, recent findings demonstrated that new vessel formation can occur also postnatally, in malignant or ischaemic tissues and in wound healing, and not only during embryonic development, reverting a common assumption accepted for decades (11). Therefore, the inhibition of angiogenesis and vasculogenesis is a promising therapeutic target for cancer, whilst their enhancement holds great potential in wound healing and tissue engineering (12). Recently, anti-angiogenic therapy targeting angiogenic growth factors has been found to have antitumor effect, and some molecules have since been granted approval for clinical use. Targeting of vascular endothelial growth factor (VEGF) and VEGF receptors (using bevacizumab and aflibercept) $(13,14,15)$, inhibition of EGF receptor and RAS-ERK pathway (using Tarceva and Cetuximab) (16) and PDGF receptor tyrosine kinases (using sunitinib) $(17,18)$ are among the most promising therapeutic strategies. Moreover, anti-VEGF and PDGF therapies have been reported to effectively decrease angiogenesis in patients affected by age-related macular degeneration and diabetic retinopathy $(14,19)$. However, despite the overall preclinical success of targeting VEGF or other angiogenic factors, it is unclear why some patients and several tissue types show resistance or only a limited or heterogeneous response to anti-VEGF compounds (20). The angiogenesis trials in many cases have therefore not reached the significant efficacy anticipated in promising preclinical studies. It suggests that we should refine molecular targets and further understand the underlying complexities of angiogenesis in addition to the mechanisms of action of the agents. To improve patient outcomes and achieve more transformative and effective therapies, we should incorporate new, novel vascular models and validate related predictive biomarkers (e.g. cell cycle, proliferation, energy metabolism and survival) to optimise these therapies specific to different tissues. With this aim in mind, consensus guidelines on angiogenesis bioassays were published in 2018 (21). This is the most exhaustive attempt to provide an in-depth assessment of the approaches used to study angiogenesis and their associated limitations.

\section{In vivo angiogenesis models}

To date, vasculogenesis and angiogenesis have largely been studied in mammalian models. The hindlimb ischaemia model, often performed in mice, allows for the reduction in blood flow to the hindlimb to be determined following ligation of the femoral artery. The subsequent enhancement following treatment is often assessed by laser-Doppler perfusion imaging. Although a powerful technique, the endogenous capability of smaller mammals to restore blood flow via post-ischaemic angiogenesis makes an assessment of therapeutic efficacy challenging (22). Zebrafish present themselves as an alternative model to investigate in vivo vascular development, in part, due to their relatively low costs resulting in hundreds of fertilised eggs per weeks, capable of fast development. The transparency of the zebrafish embryo allows for real-time visualisation of angiogenesis. Moreover, the zebrafish genome has been sequenced showing a high level of conservation with human coding protein sequences (23). Additionally, this allows for the easy generation of various transgenic lines for the expression of reporter proteins and intravital visualisation with fewer ethical considerations. While zebrafish are broadly applicable to gain a comprehensive understanding of angiogenic processes in vivo, however, this model has also some limitations. 
Fish embryos and larvae are small but constantly grow which poses challenges in longitudinal live imaging. In fact, adult fish lose transparency, dynamics and spatial characteristics of angiogenesis can be therefore technically difficult at this later stage of development. We believe complementary mammalian systems may be necessary for translation of results, given that zebrafish has aquatic, distinct respiratory and cardiovascular architecture. Also, for gene editing approaches, high gene functional conservation between zebrafish and mammals is not complete (24). More recently, lineage tracing approaches have become possible also for mouse models. Mosaic mouse lines with Brainbow (25) or inducible fluorescent genetic mosaic (ifgMosaic) technologies (26) show stochastic expression of multicolour fluorescent proteins specifically in endothelial cells. These models permit fate mapping and 3D visualisation of the clonal dynamics within the vascularised tissue during homeostasis or regeneration as well as in response to angiogenic agents at high cellular and temporal resolution.

\section{Sources of endothelial cells}

During vascular morphogenesis, endothelial cells migrate, differentiate, proliferate and aggregate to form 3D tubular structures, which become new vessels. With all systems, the source of endothelial cells is of fundamental importance to the study results. Primary endothelial cells can form vascular networks in vitro and are a common cell source for modelling angiogenesis and study cardiovascular function and diseases, as they can be easily derived and expanded from human circulating blood (endothelial colonyforming cells) (27) or solid tissues, such as cord blood (human umbilical vein endothelial cells, HUVEC) (28), aortic (human aortic endothelial cells, HAEC) (29) and lung tissues (human lung endothelial cells, hLEC) (30). However, scarce availability of tissues, low cell expansion rate and the loss of differentiated phenotype in culture limit their usage (31). Moreover, primary endothelial cells show considerable heterogeneity depending on donor-to-donor variations and tissues of origin, which reflect differences between endothelial populations derived from arteries or veins $(20,32)$, small or large vessels (33) and normal or tumour vessels. Such heterogenicity must be considered when choosing the cell source for in vitro and in vivo analyses. Pluripotent stem cells (PSCs), including embryonic (ESC) and induced pluripotent (iPSC), are a promising alternative for overcoming these limitations, as for their ability to self-renew indefinitely in culture and differentiate into different cell fates. In many protocols, first mesoderm specification is induced by the addition of Activin A, and then a vascular specification media is used, supplemented with various combinations of metabolites and growth factors (such as VEGF, FGF-2 and BMP4) which promote the differentiation of hPSC into pluripotent stem cell-derived endothelial cells (hPSC-EC) $(34,35,36)$. These cells express endothelial markers, grow as a homogenous cell monolayer with cobblestone morphology, show clonal proliferative potential and can form vessel-like networks in vitro and in vivo when supported by a hydrogel matrix. Furthermore, arterial phenotype specification was promoted in hPSC-EC cultures exposed to shear stress, as demonstrated by the upregulation of arterial markers Ephrin B2 and Notch1 (37). However, whilst it is now possible to obtain large numbers of hPSC-EC, optimisation of the culture condition is still needed to assess phenotype stability and maintenance of functional properties of hPSC-EC after several passages in culture (30). Finally, mesenchymal stem cells (MSCs) have shown vascular regeneration properties in vitro and in vivo, either by direct differentiation into smooth muscle cells (SMC) and endothelial cells or by the secretion of paracrine factors $(38,39)$.

\section{Cell culture media}

Given that endothelial cells are highly versatile and are regulated by a multitude of factors, an appropriate selection of growth factors and supplements for angiogenesis assays is critical. To support this effort, various culture media are available, which essentially differ in the composition of supplements. The best characterised angiogenic components used include VEGF, FGF2 (fibroblast growth factor 2), EGF and IGF1 (insulin-like growth factor 1). Alternatively, some media are supplemented with defined concentrations of recombinant growth factors, whereas other media contain bovine-derived endothelial cell growth supplements that are rich in undefined growthpromoting molecules. Media can be also supplemented with hydrocortisone or may contain l-glutamine, heparin and ascorbic acid. However, optimised and standardised media composition for each assay are still warranted (39).

\section{Phenotypic specification of hESC-EC}

Phenotype specification in hPSC-EC cultures is assessed by the expression of common endothelial markers, clonal proliferative potential, monolayer growth and 
cobblestone-like morphology, together with functional analyses, such as tube formation assay and acetylated lowdensity lipoprotein (AcLDL) uptake. After purification, cells express CD31, VE-Cadherin, von Willebrand Factor, Neuropilin-1, CD34, VEGFR and laminin alpha 4, as demonstrated by FACS or immunofluorescence analysis (35, 36, 40). Moreover, hPSC-EC showed a similar transcriptional signature and metabolomic profile to primary endothelial cultures (HUVEC, HAEC, and human saphenous vein EC), when gene expression profiles and metabolites were compared by RNA-sequencing and liquid chromatography mass spectrometry respectively $(35,41)$. However, variations in the expression profiles are expected, depending on the protocol used for the differentiation and time point of the analysis. Importantly, primary EC profiles did not perfectly mimic their native counterpart in vivo, raising an important issue about the best control that should be used as comparison for hPSC-EC cultures. Finally, differences in the expression of extracellular matrix components between mature endothelial cells such as HUVEC and hPSC-EC were observed, like differential expression of laminins, perlecan, matrix metallopeptidases MMP1, MMP2 and MMP14, and collagen IV a1 and a2 subunits (36).

\section{In vitro 3D models}

In alternative to in vivo models, in vitro systems can be used to study vasculogenesis and angiogenesis in a controlled, reproducible and cost-effective way. These are easier than animal models and can be used to identify cell types, molecular factors and single steps of vascular morphogenesis. For many decades, 2D-cell culture has been the traditional method of growing cells and studying their interactions. However, investigators have come to understand that the 3D microenvironment determines how cells perceive and interpret biochemical signals, which in turn translates into tissue and organ specificity (42). Recent advances in generating highfidelity, in vivo-like cellular settings can provide us with consistent performance with reduced cell culture artefacts and permit continuous and quantitative imaging. We suggest that scaffold-based cell constructs, as well as organoids, spheroids, hydrogels, and bioprinting (3D) cultures, can facilitate this by providing physiologically relevant models compared to a monolayer (2D) vascular cell culture. Cell behaviour is strongly influenced by cell-cell interactions and microenvironmental cues, i.e. signalling can change when the same cell type is cultured in 3D instead of 2D. 3D cell cultures can be therefore well used in the optimisation of tissue-engineered cell therapy manufacturing, including adequate vascularisation. To study the effect of biomaterials and growth factors that direct the process of angiogenesis, numerous models have been established $(43,44)$ (Table 1$)$. 3D cell systems have been proved to be advantageous compared to $2 \mathrm{D}$ as they allow superior reproduction of the physiological environment of cells in vivo, by maintaining cell-to-cell and cell-to-matrix interactions that control development, differentiation and signalling (45). 3D cell culture methods can be divided into two classes: scaffold-based and scaffold-free models.

\section{Scaffold-based models}

Hydrogels recapitulate the molecular environments of ECM in vivo, giving cells a 3D support matrix that they can interact with and are capable of remodelling. Hydrogels are often used in vitro to create models of angiogenesis, and they have shown potential for the study of both vascular morphogenesis and the preclinical testing of drugs (46). Different types of synthetic hydrogels have been shown to support angiogenesis, both of natural (alginate, hyaluronic acid, fibrin and gelatin) and non-natural origin (polyethylene glycol and poly (lactic-co-glycolic acid)). Collagen I and Matrigel are commonly used natural ECMbased hydrogels, although their animal origin, batch-tobatch variation and unknown composition limit their application. The advantage of hydrogels is their ability to encapsulate and release bioactive agents. Immobilisation of regulatory factors, such as RGD peptides and VEGF, in hydrogels, promote vascular differentiation of encapsulated cells (47). More recently, combining hydrogels, bioactive agents and a co-culture system have provided a model of tumour angiogenesis to further understand the role of endothelial cells in the tumour microenvironment (48). Hydrogel can be also incorporated into microfluidic systems (49). However, the composition and the density of fibres in the hydrogels have severe effects on the assembly of the microvasculature (50). For example, while increasing the fibre density usually improves the integrity of the hydrogels, however, augmenting collagen density by one order of magnitude decreased EC sprouting distance by 50\% (50, 51). At the same time, the concentration cannot be too low, as low-density hydrogels do not provide enough support for EC migration (52). Moreover, matrix biodegradability was shown to profoundly alter EC migration speed and efficiency, with less-biodegradable hydrogels encouraging

This work is licensed under a Creative Commons Attribution 4.0 International License. 

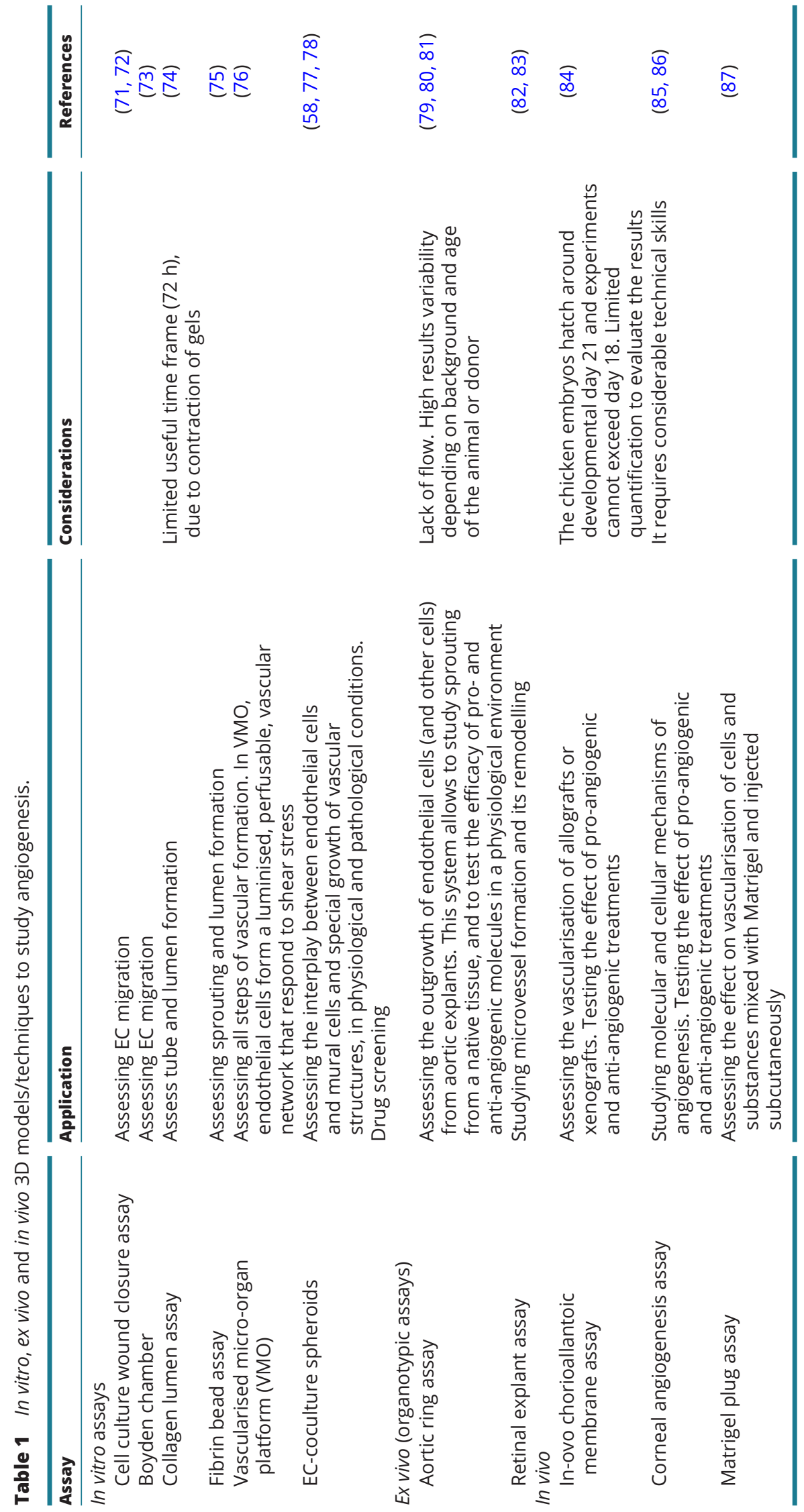
EC sprouting compared to more-degradable ones $(53,54)$. Finally, stiffness of the substrate can also influence EC proliferation, signalling and differentiation (55), Therefore, ECM protein composition and concentration must be carefully optimised to ensure that hydrogels promote vascularisation while maintaining their structural integrity.

\section{Scaffold-free models}

However, the advent of spheroids systems has provided a new method to study angiogenesis in vitro. Here, the addition of synthetic-derived scaffold to mimic the ECM is not required, and instead, cells are grown as selfassembling aggregates. In these 3D systems, the cells grow, differentiate and deposit their own ECM, in a way that closely recapitulates the in vivo physiological conditions. Spheroids can be used to study the physiological spatial growth of vessel structures, the cell-cell interactions, and as a platform for drug development and discovery (30). Hybrid spheroids, generated by co-culturing two or three types of cell, are useful models to study the interaction between endothelial and tumour/stroma cells in different in vitro models of cancer $(56,57)$ or between endothelial and mural cells in angiogenesis/vasculogenesis. Analysis of endothelial cell/MSC spheroids showed that MSC participated in the formation and stabilisation of luminal tubular structures, similarly to pericyte-like cells $(58,59)$. Many methods can be used to generate the spheroids including hanging drops, low adhesion plates and self-organising $3 \mathrm{D}$ vessel-like structures (vascular organoids) (60). Notwithstanding the versatility and cost-effectiveness of scaffold-free models, the cell density and dimensions of the spheroids must be carefully monitored, as oxygen and nutrients diffusion to the core might be affected. Consequently, time in culture may be as well limited (14). Finally, as 3D culture systems become more popular and continue to evolve, more sophisticated imaging techniques need to be developed to image and analyse thick samples (61).

\section{Microfluidic devices for in vitro 3D assays}

A major challenge remains to find a 3D system capable of mimicking the physiological and pathological conditions of the in vivo systems. We know that in vivo the vascular endothelium is continuously exposed to shear stress and hypoxia, and EC physiology varies in response to different flow patterns and rates compared to static culture conditions (62). Moreover, for 3D culture systems, it is essential to improve medium diffusion, oxygen and nutrients supply to ensure cell survival in the core of the microtissues. Application of flow to angiogenic culture models is the most distinctive advantage of using microfluidics, other than reducing costs and complexity of the experiments and minimizing the volume of reagents $(63,64)$. Furthermore, in vitro microfluidic systems allowed to study in a controlled manner the effects of normal and disturbed flow on endothelial cells and the interactions between endothelial cells, supporting cells (pericytes and SMC) and platelet $(65,66,67,68)$.

However, the designing of microfluidic devices requires specific competencies which are usually beyond the expertise of the final operators, and some limitations remain in the application of microfluidic systems $(69,70)$.

\section{Conclusions}

Recent progress in 3D models of vascularisation has allowed for invaluable advancements in our knowledge of angiogenesis/vasculogenesis. In this review, for each model we reported advantages and limitations. Different tests should be used together to obtain the maximum of information. In vitro tests, although informative, are yet unable to divulge the more complex interactions between endothelial cells and other cellular constituents of the microvessel wall or the response to flow or shear stress which plays an important role in vascular mechanobiology and should be complemented with in vivo models.

\section{Declaration of interest}

The authors declare that there is no conflict of interest that could be perceived as prejudicing the impartiality of this review.

\section{Funding}

This work was supported by the BHF Regenerative Medicine Centre, the Medical Research Council (MR/R025002/1) and the Hungarian National Research, Development and Innovation Fund (NVKP-16-1-2016-0017 and 128444).

\section{References}

1 Adams RH \& Alitalo K. Molecular regulation of angiogenesis and lymphangiogenesis. Nature Reviews: Molecular Cell Biology 20078 464-478. (https://doi.org/10.1038/nrm2183)

2 Gong MM, Lugo-Cintron KM, White BR, Kerr SC, Harari PM \& Beebe DJ. Human organotypic lymphatic vessel model elucidates microenvironment-dependent signaling and barrier function.

\section{This work is licensed under a Creative Commons} Attribution 4.0 International License. 
Biomaterials 2019214 119225. (https://doi.org/10.1016/j. biomaterials.2019.119225)

3 Patan S. Vasculogenesis and angiogenesis as mechanisms of vascular network formation, growth and remodeling. Journal of NeuroOncology 200050 1-15. (https://doi.org/10.1023/a:1006493130855)

4 Dhaval K, McClung JA \& Aronow WS. Vasculogenesis and angiogenesis. In Translational Research in Coronary Artery Disease, 1st ed., ch 6, pp 49-65. Eds W Aronow \& JA McClung. Academic Press, 2015.

5 Risau W. Mechanisms of angiogenesis. Nature 1997386 671-674. (https://doi.org/10.1038/386671a0)

6 Carmeliet P \& Jain RK. Molecular mechanisms and clinical applications of angiogenesis. Nature 2011473 298-307. (https://doi. org/10.1038/nature10144)

7 Eilken HM \& Adams RH. Dynamics of endothelial cell behavior in sprouting angiogenesis. Current Opinion in Cell Biology 201022 617-625. (https://doi.org/10.1016/j.ceb.2010.08.010)

8 Caduff JH, Fischer LC \& Burri PH. Scanning electron microscope study of the developing microvasculature in the postnatal rat lung. Anatomical Record 1986216 154-164. (https://doi.org/10.1002/ ar.1092160207)

9 Burri PH \& Tarek MR. A novel mechanism of capillary growth in the rat pulmonary microcirculation. Anatomical Record 1990228 35-45. (https://doi.org/10.1002/ar.1092280107)

10 Folkman J. Tumor angiogenesis: therapeutic implications. New England Journal of Medicine 1971285 1182-1186. (https://doi. org/10.1056/NEJM197111182852108)

11 Asahara T, Masuda H, Takahashi T, Kalka C, Pastore C, Silver M, Kearne M, Magner M \& Isner JM. Bone marrow origin of endothelial progenitor cells responsible for postnatal vasculogenesis in physiological and pathological neovascularization. Circulation Research 199985 221-228. (https://doi.org/10.1161/01.res.85.3.221)

12 Lovett M, Lee K, Edwards A \& Kaplan DL. Vascularization strategies for tissue engineering. Tissue Engineering: Part B, Reviews 200915 353-370. (https://doi.org/10.1089/ten.TEB.2009.0085)

13 Apte RS, Chen DS \& Ferrara N. VEGF in signaling and disease: beyond discovery and development. Cell 2019176 1248-1264. (https://doi.org/10.1016/j.cell.2019.01.021)

14 Ferrara N \& Adamis AP. Ten years of anti-vascular endothelial growth factor therapy. Nature Reviews: Drug Discovery 201615 385-403. (https://doi.org/10.1038/nrd.2015.17)

15 Yla-Herttuala S \& Baker AH. Cardiovascular gene therapy: past, present, and future. Molecular Therapy 201725 1095-1106. (https:// doi.org/10.1016/j.ymthe.2017.03.027)

16 Pozzi C, Cuomo A, Spadoni I, Magni E, Silvola A, Conte A, Sigismund S, Ravenda PS, Bonaldi T, Zampino MG, et al. The EGFRspecific antibody cetuximab combined with chemotherapy triggers immunogenic cell death. Nature Medicine 201622 624-631. (https:// doi.org/10.1038/nm.4078)

17 Sternberg CN, Davis ID, Mardiak J, Szczylik C, Lee E, Wagstaff J, Barrios CH, Salman P, Gladkov OA, Kavina A, et al. Pazopanib in locally advanced or metastatic renal cell carcinoma: results of a randomized phase III trial. Journal of Clinical Oncology 201028 1061-1068. (https://doi.org/10.1200/JCO.2009.23.9764)

18 Motzer RJ, Hutson TE, Tomczak P, Michaelson MD, Bukowski RM, Oudard S, Negrier S, Szczylik C, Pili R, Bjarnason GA, et al. Overall survival and updated results for sunitinib compared with interferon alfa in patients with metastatic renal cell carcinoma. Journal of Clinical Oncology 200927 3584-3590. (https://doi.org/10.1200/ JCO.2008.20.1293)

19 Almuhtaseb H, Kanavati S, Rufai SR \& Lotery AJ. One-year realworld outcomes in patients receiving fixed-dosing aflibercept for neovascular age-related macular degeneration. Eye 201731 878-883. (https://doi.org/10.1038/eye.2017.6)

20 Lawson ND, Scheer N, Pham VN, Kim CH, Chitnis AB, CamposOrtega JA \& Weinstein BM. Notch signaling is required for arterial- venous differentiation during embryonic vascular development. Development 2001128 3675-3683.

21 Nowak-Sliwinska P, Alitalo K, Allen E, Anisimov A, Aplin AC, Auerbach R, Augustin HG, Bates DO, van Beijnum JR, Bender RHF, et al. Consensus guidelines for the use and interpretation of angiogenesis assays. Angiogenesis 201821 425-532. (https://doi. org/10.1007/s10456-018-9613-x)

22 Couffinhal T, Silver M, Zheng LP, Kearney M, Witzenbichler B \& Isner JM. Mouse model of angiogenesis. American Journal of Pathology 1998152 1667-1679.

23 Howe K, Clark MD, Torroja CF, Torrance J, Berthelot C, Muffato M, Collins JE, Humphray S, McLaren K, Matthews L, et al. The zebrafish reference genome sequence and its relationship to the human genome. Nature 2013496 498-503. (https://doi.org/10.1038/ nature12111)

24 Chavez MN, Aedo G, Fierro FA, Allende ML \& Egana JT. Zebrafish as an emerging model organism to study angiogenesis in development and regeneration. Frontiers in Physiology 20167 56. (https://doi. org/10.3389/fphys.2016.00056)

25 Livet J, Weissman TA, Kang H, Draft RW, Lu J, Bennis RA, Sanes JR \& Lichtman JW. Transgenic strategies for combinatorial expression of fluorescent proteins in the nervous system. Nature $2007 \mathbf{4 5 0} 56-62$. (https://doi.org/10.1038/nature06293)

26 Pontes-Quero S, Fernandez-Chacon M, Luo W, Lunella FF, CasqueroGarcia V, Garcia-Gonzalez I, Hermoso A, Rocha SF, Bansal M \& Benedito R. High mitogenic stimulation arrests angiogenesis. Nature Communications 201910 2016. (https://doi.org/10.1038/s41467-01909875-7)

27 Medina RJ, Barber CL, Sabatier F, Dignat-George F, Melero-Martin JM, Khosrotehrani K, Ohneda O, Randi AM, Chan JKY, Yamaguchi T, et al. Endothelial progenitors: a consensus statement on nomenclature. Stem Cells Translational Medicine 20176 1316-1320. (https://doi.org/10.1002/sctm.16-0360)

28 Baudin B, Bruneel A, Bosselut N \& Vaubourdolle M. A protocol for isolation and culture of human umbilical vein endothelial cells. Nature Protocols 20072 481-485. (https://doi.org/10.1038/ nprot.2007.54)

29 Leclercq A, Veillat V, Loriot S, Spuul P, Madonna F, Roques X \& Genot E. A methodology for concomitant isolation of intimal and adventitial endothelial cells from the human thoracic aorta PLOS ONE 201510 e0143144. (https://doi.org/10.1371/journal. pone.0143144)

30 Comhair SA, Xu W, Mavrakis L, Aldred MA, Asosingh K \& Erzurum SC. Human primary lung endothelial cells in culture. American Journal of Respiratory Cell and Molecular Biology 201246 723-730. (https://doi.org/10.1165/rcmb.2011-0416TE)

31 Olmer R, Engels L, Usman A, Menke S, Malik MNH, Pessler F, Gohring G, Bornhorst D, Bolten S, Abdelilah-Seyfried S, et al. Differentiation of human pluripotent stem cells into functional endothelial cells in scalable suspension culture. Stem Cell Reports 201810 1657-1672. (https://doi.org/10.1016/j. stemcr.2018.03.017)

32 Chi JT, Chang HY, Haraldsen G, Jahnsen FL, Troyanskaya OG, Chang DS, Wang Z, Rockson SG, van de Rijn M, Botstein D, et al. Endothelial cell diversity revealed by global expression profiling. PNAS 2003100 10623-10628. (https://doi.org/10.1073/ pnas.1434429100)

33 Muller AM, Hermanns MI, Skrzynski C, Nesslinger M, Muller KM \& Kirkpatrick CJ. Expression of the endothelial markers PECAM-1, vWf, and CD34 in vivo and in vitro. Experimental and Molecular Pathology 200272 221-229. (https://doi.org/10.1006/exmp.2002.2424)

34 Prasain N, Lee MR, Vemula S, Meador JL, Yoshimoto M, Ferkowicz MJ, Fett A, Gupta M, Rapp BM, Saadatzadeh MR, et al. Differentiation of human pluripotent stem cells to cells similar to cord-blood endothelial colony-forming cells. Nature Biotechnology 201432 1151-1157. (https://doi.org/10.1038/nbt.3048) 
35 Patsch C, Challet-Meylan L, Thoma EC, Urich E, Heckel T, O'Sullivan JF, Grainger SJ, Kapp FG, Sun L, Christensen K, et al. Generation of vascular endothelial and smooth muscle cells from human pluripotent stem cells. Nature Cell Biology 201517 994-1003. (https://doi.org/10.1038/ncb3205)

36 Nguyen MTX, Okina E, Chai X, Tan KH, Hovatta O, Ghosh S \& Tryggvason K. Differentiation of human embryonic stem cells to endothelial progenitor cells on laminins in defined and xeno-free systems. Stem Cell Reports 20167 802-816. (https://doi.org/10.1016/j. stemcr.2016.08.017)

37 Sivarapatna A, Ghaedi M, Le AV, Mendez JJ, Qyang Y \& Niklason LE. Arterial specification of endothelial cells derived from human induced pluripotent stem cells in a biomimetic flow bioreactor. Biomaterials 201553 621-633. (https://doi.org/10.1016/j. biomaterials.2015.02.121)

38 Rehman J, Traktuev D, Li J, Merfeld-Clauss S, Temm-Grove CJ, Bovenkerk JE, Pell CL, Johnstone BH, Considine RV \& March KL. Secretion of angiogenic and antiapoptotic factors by human adipose stromal cells. Circulation 2004109 1292-1298. (https://doi. org/10.1161/01.CIR.0000121425.42966.F1)

39 Nakagami H, Maeda K, Morishita R, Iguchi S, Nishikawa T, Takami Y, Kikuchi Y, Saito Y, Tamai K, Ogihara T, et al. Novel autologous cell therapy in ischemic limb disease through growth factor secretion by cultured adipose tissue-derived stromal cells. Arteriosclerosis, Thrombosis, and Vascular Biology 200525 2542-2547. (https://doi. org/10.1161/01.ATV.0000190701.92007.6d)

40 Orlova VV, van den Hil FE, Petrus-Reurer S, Drabsch Y, Ten Dijke P $\&$ Mummery CL. Generation, expansion and functional analysis of endothelial cells and pericytes derived from human pluripotent stem cells. Nature Protocols 20149 1514-1531. (https://doi.org/10.1038/ nprot.2014.102)

41 Vila-Gonzalez M, Kelaini S, Magee C, Caines R, Campbell D, Eleftheriadou M, Cochrane A, Drehmer D, Tsifaki M, O'Neill K, et al. Enhanced function of induced pluripotent stem cell-derived endothelial cells through ESM1 signaling. Stem Cells 201937 226-239. (https://doi.org/10.1002/stem.2936)

42 Dellian M, Witwer BP, Salehi HA, Yuan F \& Jain RK. Quantitation and physiological characterization of angiogenic vessels in mice: effect of basic fibroblast growth factor, vascular endothelial growth factor/ vascular permeability factor, and host microenvironment. American Journal of Pathology 1996149 59-71.

43 Norrby K. In vivo models of angiogenesis. Journal of Cellular and Molecular Medicine 200610 588-612. (https://doi. org/10.1111/j.1582-4934.2006.tb00423.x)

44 Poulaki V. Angiogenesis assays. Methods in Molecular Biology 2011731 345-358. (https://doi.org/10.1007/978-1-61779-080-5_28)

45 Grist SM, Nasseri SS, Poon T, Roskelley C \& Cheung KC. On-chip clearing of arrays of 3-D cell cultures and microtissues. Biomicrofluidics 201610 044107. (https://doi. org/10.1063/1.4959031)

46 Zeitlin BD, Dong Z \& Nor JE. RAIN-Droplet: a novel 3D in vitro angiogenesis model. Laboratory Investigation 201292 988-998. (https://doi.org/10.1038/labinvest.2012.77)

47 Ferreira LS, Gerecht S, Fuller J, Shieh HF, Vunjak-Novakovic G \& Langer R. Bioactive hydrogel scaffolds for controllable vascular differentiation of human embryonic stem cells. Biomaterials $2007 \mathbf{2 8}$ 2706-2717. (https://doi.org/10.1016/j.biomaterials.2007.01.021)

48 Chwalek K, Bray LJ \& Werner C. Tissue-engineered 3D tumor angiogenesis models: potential technologies for anti-cancer drug discovery. Advanced Drug Delivery Reviews 2014 79-80 30-39. (https://doi.org/10.1016/j.addr.2014.05.006)

49 Kuzmic N, Moore T, Devadas D \& Young EWK. Modelling of endothelial cell migration and angiogenesis in microfluidic cell culture systems. Biomechanics and Modeling in Mechanobiology 2019 18 717-731. (https://doi.org/10.1007/s10237-018-01111-3)
50 Vernon RB \& Sage EH. A novel, quantitative model for study of endothelial cell migration and sprout formation within threedimensional collagen matrices. Microvascular Research 199957 118-133. (https://doi.org/10.1006/mvre.1998.2122)

51 Nehls V \& Drenckhahn D. A novel, microcarrier-based in vitro assay for rapid and reliable quantification of three-dimensional cell migration and angiogenesis. Microvascular Research 199550 311-322. (https://doi.org/10.1006/mvre.1995.1061)

52 Shamloo A \& Heilshorn SC. Matrix density mediates polarization and lumen formation of endothelial sprouts in VEGF gradients. Lab on a Chip 201010 3061-3068. (https://doi.org/10.1039/c005069e)

53 Unterman S, Freiman A, Beckerman M, Abraham E, Stanley JR, Levy E, Artzi N \& Edelman E. Tuning of collagen scaffold properties modulates embedded endothelial cell regulatory phenotype in repair of vascular injuries in vivo. Advanced Healthcare Materials 20154 2220-2228. (https://doi.org/10.1002/adhm.201500457)

54 Trappmann B, Baker BM, Polacheck WJ, Choi CK, Burdick JA \& Chen CS. Matrix degradability controls multicellularity of 3D cell migration. Nature Communications 20178371 . (https://doi. org/10.1038/s41467-017-00418-6)

55 LaValley DJ, Zanotelli MR, Bordeleau F, Wang W, Schwager SC \& Reinhart-King CA. Matrix stiffness enhances VEGFR-2 internalization, signaling, and proliferation in endothelial cells. Convergent Science Physical Oncology 20173 044001. (https://doi. org/10.1088/2057-1739/aa9263)

56 Amann A, Zwierzina M, Koeck S, Gamerith G, Pechriggl E, Huber JM, Lorenz E, Kelm JM, Hilbe W, Zwierzina H, et al. Development of a 3D angiogenesis model to study tumour - endothelial cell interactions and the effects of anti-angiogenic drugs. Scientific Reports $2017 \mathbf{7}$ 2963. (https://doi.org/10.1038/s41598-017-03010-6)

57 Shoval H, Karsch-Bluman A, Brill-Karniely Y, Stern T, Zamir G, Hubert A \& Benny O. Tumor cells and their crosstalk with endothelial cells in 3D spheroids. Scientific Reports $2017 \mathbf{7} 10428$. (https://doi.org/10.1038/s41598-017-10699-y)

58 Duttenhoefer F, Lara de Freitas R, Meury T, Loibl M, Benneker LM Richards RG, Alini M \& Verrier S. 3D scaffolds co-seeded with human endothelial progenitor and mesenchymal stem cells: evidence of prevascularisation within 7 days. European Cells and Materials 2013 26 49-64; discussion 64. (https://doi.org/10.22203/ecm.v026a04)

59 Shah S \& Kang KT. Two-cell spheroid angiogenesis assay system using both endothelial colony forming cells and mesenchymal stem cells. Biomolecules and Therapeutics 201826 474-480. (https://doi. org/10.4062/biomolther.2018.134)

60 Wimmer RA, Leopoldi A, Aichinger M, Wick N, Hantusch B, Novatchkova M, Taubenschmid J, Hammerle M, Esk C, Bagley JA, et al. Human blood vessel organoids as a model of diabetic vasculopathy. Nature 2019565 505-510. (https://doi.org/10.1038/ s41586-018-0858-8)

61 Calve S, Ready A, Huppenbauer C, Main R \& Neu CP. Optical clearing in dense connective tissues to visualize cellular connectivity in situ. PLoS ONE 201510 e0116662. (https://doi.org/10.1371/journal. pone.0116662)

62 Franke RP, Grafe M, Schnittler H, Seiffge D, Mittermayer C \& Drenckhahn D. Induction of human vascular endothelial stress fibres by fluid shear stress. Nature $1984 \mathbf{3 0 7}$ 648-649. (https://doi. org/10.1038/307648a0)

63 Katt ME, Placone AL, Wong AD, Xu ZS \& Searson PC. In vitro tumor models: advantages, disadvantages, variables, and selecting the right platform. Frontiers in Bioengineering and Biotechnology 2016412. (https://doi.org/10.3389/fbioe.2016.00012)

64 Kim S, Lee H, Chung M \& Jeon NL. Engineering of functional, perfusable 3D microvascular networks on a chip. Lab on a Chip 2013 13 1489-1500. (https://doi.org/10.1039/c3lc41320a)

65 Estrada R, Giridharan GA, Nguyen MD, Prabhu SD \& Sethu P. Microfluidic endothelial cell culture model to replicate disturbed flow (c) 2019 The authors Published by Bioscientifica Ltd

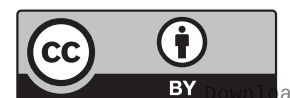

This work is licensed under a Creative Commons Attribution 4.0 International License. 
conditions seen in atherosclerosis susceptible regions. Biomicrofluidics 20115 32006-3200611. (https://doi.org/10.1063/1.3608137)

66 Song JW \& Munn LL. Fluid forces control endothelial sprouting. PNAS 2011108 15342-15347. (https://doi.org/10.1073/ pnas.1105316108)

67 Kim J, Chung M, Kim S, Jo DH, Kim JH \& Jeon NL. Engineering of a biomimetic pericyte-covered 3D microvascular network. PLOS ONE 201510 e0133880. (https://doi.org/10.1371/journal. pone.0133880)

68 Zheng Y, Chen J, Craven M, Choi NW, Totorica S, Diaz-Santana A, Kermani P, Hempstead B, Fischbach-Teschl C, Lopez JA, et al. In vitro microvessels for the study of angiogenesis and thrombosis. PNAS 2012109 9342-9347. (https://doi.org/10.1073/pnas.1201240109)

69 Berthier E, Young EW \& Beebe D. Engineers are from PDMS-land, biologists are from Polystyrenia. Lab on a Chip 201212 1224-1237. (https://doi.org/10.1039/c2lc20982a)

70 Shirure VS \& George SC. Design considerations to minimize the impact of drug absorption in polymer-based organ-on-a-chip platforms. Lab on a Chip 201717 681-690. (https://doi.org/10.1039/ c6lc01401a)

71 Sato Y \& Rifkin DB. Inhibition of endothelial cell movement by pericytes and smooth muscle cells: activation of a latent transforming growth factor-beta 1-like molecule by plasmin during co-culture. Journal of Cell Biology 1989109 309-315. (https://doi. org/10.1083/jcb.109.1.309)

72 Williams SP, Gould CM, Nowell CJ, Karnezis T, Achen MG, Simpson KJ \& Stacker SA. Systematic high-content genome-wide RNAi screens of endothelial cell migration and morphology. Scientific Data 20174 170009. (https://doi.org/10.1038/sdata.2017.9)

73 BOYDEN S. The chemotactic effect of mixtures of antibody and antigen on polymorphonuclear leucocytes. Journal of Experimental Medicine 1962115 453-466. (https://doi.org/10.1084/jem.115.3.453)

74 Montesano R, Orci L \& Vassalli P. In vitro rapid organization of endothelial cells into capillary-like networks is promoted by collagen matrices. Journal of Cell Biology 198397 1648-1652. (https://doi. org/10.1083/jcb.97.5.1648)

75 Nakatsu MN \& Hughes CC. An optimized three-dimensional in vitro model for the analysis of angiogenesis. Methods in Enzymology 2008 443 65-82. (https://doi.org/10.1016/S0076-6879(08)02004-1)

76 Wang X, Phan DTT, George SC, Hughes CCW \& Lee AP. 3D anastomosed microvascular network model with living capillary networks and endothelial cell-lined microfluidic channels. Methods in Molecular Biology 20171612 325-344. (https://doi.org/10.1007/9781-4939-7021-6_24)
77 Lazzari G, Nicolas V, Matsusaki M, Akashi M, Couvreur P \& Mura S. Multicellular spheroid based on a triple co-culture: a novel 3D model to mimic pancreatic tumor complexity. Acta Biomaterialia 201878 296-307. (https://doi.org/10.1016/j.actbio.2018.08.008)

78 Upreti M, Jamshidi-Parsian A, Koonce NA, Webber JS, Sharma SK, Asea AA, Mader MJ \& Griffin RJ. Tumor-endothelial cell threedimensional spheroids: new aspects to enhance radiation and drug therapeutics. Translational Oncology 20114 365-376. (https://doi. org/10.1593/tlo.11187)

79 Nicosia RF \& Ottinetti A. Growth of microvessels in serum-free matrix culture of rat aorta. A quantitative assay of angiogenesis in vitro. Laboratory Investigation 199063 115-122.

80 Burbridge MF \& West DC. Rat aortic ring: 3D model of angiogenesis in vitro. Methods in Molecular Medicine 200146 185-204. (https://doi. org/10.1385/1-59259-143-4:185)

81 Muthukkaruppan VR, Shinneers BL, Lewis R, Park S-J, Baechler BJ \& Auerbach R. The chick embryo aortic arch assay: a new, rapid quantifiable in vitro method for testing the efficacy of angiogenic and anti-angiogenic factors in a three-dimensional, serum-free organ culture system. Proceedings of the American Association for Cancer Research $2000 \mathbf{4 1} 65$.

82 Sawamiphak S, Ritter M \& Acker-Palmer A. Preparation of retinal explant cultures to study ex vivo tip endothelial cell responses. Nature Protocols 20105 1659-1665. (https://doi.org/10.1038/ nprot.2010.130)

83 Rezzola S, Belleri M, Gariano G, Ribatti D, Costagliola C, Semeraro F \& Presta M. In vitro and ex vivo retina angiogenesis assays. Angiogenesis 201417 429-442. (https://doi.org/10.1007/s10456-0139398-x)

84 West DC, Thompson WD, Sells PG \& Burbridge MF. Angiogenesis assays using chick chorioallantoic membrane. Methods in Molecular Medicine 200146 107-129. (https://doi.org/10.1385/1-59259-1434:107)

85 Kenyon BM, Voest EE, Chen CC, Flynn E, Folkman J \& D'Amato RJ. A model of angiogenesis in the mouse cornea. Investigative Ophthalmology and Visual Science 199637 1625-1632.

86 Morbidelli L \& Ziche M. The rabbit corneal pocket assay. Methods in Molecular Biology 20161430 299-310. (https://doi.org/10.1007/9781-4939-3628-1_20)

87 Passaniti A, Taylor RM, Pili R, Guo Y, Long PV, Haney JA, Pauly RR, Grant DS \& Martin GR. A simple, quantitative method for assessing angiogenesis and antiangiogenic agents using reconstituted basement membrane, heparin, and fibroblast growth factor. Laboratory Investigation 199267 519-528.

Received in final form 27 November 2019

Accepted 3 December 2019

Accepted Preprint published online 3 December 2019 https://vb.bioscientifica.com

https://doi.org/10.1530/VB-19-0026 (c) 2019 The authors Published by Bioscientifica Ltd

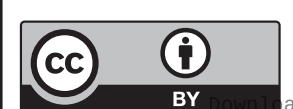

This work is licensed under a Creative Commons Attribution 4.0 International License. 